\title{
De mãos dadas: ensino e pesquisa na formação docente
}

\author{
Célia Nunes ${ }^{1}$
}

Hércules Corrêa ${ }^{2}$

\section{Resumo}

Este artigo tem como objetivo apresentar as contribuições de estudos que temos desenvolvido procurando integrar o ensino e a pesquisa junto à formação de professores das séries iniciais do Ensino Fundamental. Nossa metodologia consistiu na coleta de memoriais de leitura e escrita produzidos por alunos do curso de Pedagogia e numa análise de três memoriais escritos por alunos que, além de terem coeficiente de aproveitamento de ensino igual ou superior a nove, interagiram mais com os pesquisadores e apresentaram textos que se destacaram dos demais, tendo em vista suas reflexões e trajetórias. Os resultados mostram três textos com características bem distintas e que nos permitem desvelar as memórias e trajetórias singulares dos pedagogos em formação.

Palavras-Chave: formação de professores; memorial de leitura e escrita; narrativas docentes.

1 Doutora em Educação pela PUC-Rio. Professora do Departamento de Educação da UFOP, Brasil. cmfnunes@gmail.com

2 Doutor em Educação pela Universidade Federal de Minas Gerais. Professor do Centro de Educação Aberta e a Distância da UFOP, Minas Gerais, Brasil. herculest@uol.com.br 


\title{
Hand in hand: education and research in teacher training
}

\begin{abstract}
This paper aims to present the contributions of studies we have developed trying to integrate teaching and research with the training of teachers in the early grades of elementary school. Our methodology consisted of the collection of memorials of reading and writing produced by students of Pedagogy and an analysis of three memorials written by students who, besides having coefficient of utilization of education greater than or equal to nine, interacted more with the researchers and presented texts that stood out from the others, in light of their reflections and trajectories. The results show three texts have very different characteristics and allow us reveal memories and singular trajectories of teachers in training.
\end{abstract}

Keywords: teacher training; memorial reading and writing; narratives teachers.

Começo pelo capítulo do nascimento da personagem principal deste romance, sim, pois o que é a vida senão um romance? Um lindo e mágico romance onde tudo acontece no tempo real. (Do memorial de LisEscrevinhadora)

Esses signos/significados e significações são um feixe de intersubjetividade até porque a vida de qualquer pessoa é tecida em sua unidade alimentada pela pluralidade de encontros que ela tem em suas incessantes trocas $e$ interações - consigo, com o outro ou com o meio ambiente. Em suma - às vezes fico matutando sobre quem sou. Eu não sou eu só. Sou tessituras que a vida vai inventando/reinventando em fases e ciclos. (Do memorial de Payayá-Índio-do-Brasil)

A atividade de escrever para mim ainda é um ato difícil, por no papel o que vem a minha mente, procurando expressar o que é necessário pelo medo de tropeçar nas palavras, de errar, de não evidenciar os meus anseios, vontades e desejos através da escrita. Reencontrar com 
minha memória, adentrar o meu interior sem que tenha que pedir autorização a mim mesma, tentando ultrapassar os meus limites como pessoa, falar do meu eu, e de todo o meu caminhar até o presente momento, sem medo de exercer a felicidade, praticar a liberdade, exercer a comunicação, sentir-me aberta para uma realização que chegou nesta etapa de minha existência que é concluir a minha graduação. (Do memorial de Violeta-Prô-da-Bahia)

\section{Considerações iniciais sobre a formação docente: ensino e pesquisa}

A formação docente no contexto brasileiro tem sido tema recorrente tanto no campo das políticas como das pesquisas no campo educacional, nos quais podemos perceber a complexidade que esta temática envolve. As reformas educacionais implementadas nos últimos anos geraram diversas orientações, impactando em mudanças em várias áreas, assim como na formação do professor brasileiro. A formação docente, tanto inicial como continuada, passa a apresentar, então, novas diretrizes, objetivando o atendimento das políticas implementadas num contexto de mudanças políticas e sociais.

A Lei de Diretrizes e Bases da Educação Nacional (Lei n. 9394/96), instituída no Brasil em 1996, constitui um marco nesse campo ao dar ênfase às questões relacionadas à formação de professores em nossa realidade educacional e ao levar as instituições voltadas para formação docente a repensar e reorganizar os seus cursos na tentativa de atender as novas exigências legais.

A referida lei determinou a exigência de nível superior para os professores da Educação Básica, conforme consta em seu artigo 62:

A formação de docentes para atuar na educação básica farse-á em nível superior, em curso de licenciatura, de graduação plena, em universidades e institutos superiores de educação, admitida como formação mínima para o exercício do magistério na educação infantil e nas quatro primeiras séries do ensino fundamental, a oferecida em nível médio, na modalidade Normal. (BRASIL, 1996)

A partir desse momento no cenário brasileiro, há uma grande 
mudança visando a acompanhar a tendência mundial de universalização da formação superior dos professores. Diante dessa normativa, o curso de formação de professores passou a ser oferecido em diversas instituições, tanto na modalidade presencial quanto a distância, quais sejam: escolas normais de nível médio; universidades; Instituições de Ensino Superior (centros universitários, faculdades integradas ou faculdades isoladas; institutos superiores de educação, criados pela LDB/1996, para funcionar no interior das Instituições de Ensino Superior e mais recentemente nos Institutos Federais de Educação Tecnológica), na oferta de licenciaturas que objetivem contribuir para a educação profissional.

Essa diversidade de lócus acabou por gerar uma diferença nos processos de formação inicial dos professores brasileiros. Os cursos são organizados a partir de dois documentos básicos: Diretrizes Curriculares Nacionais para a Formação de Professores (DCNs) de 2002, para os professores que vão atuar com anos finais do Ensino Fundamental e Ensino Médio; e de 2006, para os que vão atuar com a Educação Infantil e anos inicias da educação básica.

As DCNs (BRASIL, 2002), então, instituem princípios, fundamentos e procedimentos a serem observados na organização institucional e curricular dos cursos de formação de professores. A resolução enumera as formas de orientação necessárias à formação docente, além das já dispostas pela LDB 9394/96.

Em que pesem as inúmeras discussões geradas em torno das regulamentações sobre o lócus onde se daria a formação desses professores, outra vertente ficou direcionada na discussão de "modelos" de formação que pudessem desenvolver a autonomia crítica, contrapondo o modelo da racionalidade técnica até então orientador dos processos formativos nos quais a estrutura curricular consistia em três anos de formação básica e um de formação pedagógica.

Assim, as DCNs têm como ponto principal estruturar as disciplinas dos cursos de formação docente, principalmente no que norteia a interação, o comprometimento do professor com os alunos e com o local onde atua. Preocupa-se ainda em desenvolver o trabalho de pesquisa em ambos os lados, como um reduto de conhecimento, no qual o professor 
poderá recorrer em seu processo de reflexão-ação.

Nesse direcionamento, Nóvoa (1995) nos traz a contribuição de pensarmos a formação do professor que considere tanto o seu desenvolvimento pessoal, quanto o desenvolvimento organizacional da escola. Segundo o pesquisador português, o espaço de desenvolvimento da formação docente é o lugar onde o professor constrói sua profissão. Entretanto, esta

[...] tem ignorado sistematicamente o desenvolvimento pessoal, confundindo "formar" e "formar-se", não compreendendo que a lógica da actividade educativa nem sempre coincide com as dinâmicas próprias da formação. Mas também não tem valorizado uma articulação entre a formação e os projectos das escolas, consideradas como organizações dotadas de margens de autonomia e de decisão de dia para dia mais importante. Estes dois esquecimentos inviabilizam que a formação tenha como eixo de referência o desenvolvimento profissional dos professores, na dupla perspectiva do professor individual e do coletivo docente. (NÓVOA, 1995, p. 24)

Os programas de formação docente (inicial e/ou continuada), assim como as pesquisas reconhecendo a complexidade desse processo formativo, têm utilizado as narrativas de seus participantes - aqui designadas como memoriais de leitura e escrita - no intuito de identificar suas experiências e seus contextos. Este tem sido um caminho profícuo nas pesquisas e práticas para buscar novos direcionamentos para investigação desse profissional no campo educacional. Como destaca Souza (2006),

Nas pesquisas na área de educação adota-se a história de vida, mais especificamente, o método autobiográfico e as narrativas de formação como movimento de investigação-formação, seja na formação inicial ou continuada de professores/professoras ou em pesquisas centradas nas memórias e autobiografias de professores. (p. 22)

É nessa direção que temos desenvolvido o nosso trabalho com a formação de professores na universidade onde atuamos. Por meio do desenvolvimento de atividades de ensino e pesquisa no processo de formação docente, temos buscado valorizar a voz dos sujeitos (professores e/ ou licenciandos) em seus contextos sociais, e eles passam 
do estatuto de objeto das análises para o de sujeito.

Nesse percurso, localizamos a mudança de eixo de uma visão única para uma diversidade de concepções e a valorização da experiência de vida na trajetória desses sujeitos, buscando compreender suas representações e práticas. Os docentes e/ou licenciandos vão sendo reconhecidos como portadores de saberes plurais, críticos e interativos, fundados numa experiência construída na prática, que considera a experiência pessoal e o contexto escolar nesse processo de autoformação.

As pesquisas e práticas formativas com docentes e/ou licenciandos, nesse contexto, passam a recorrer de narrativas a partir da reflexão sobre si, no "ouvir" o docente como protagonista do processo de formação e escolar. Nessa direção, Souza (2006) afirma que "A organização e construção da narrativa de si implicam colocar o sujeito em contato com suas experiências formadoras, as quais são perspectivadas a partir daquilo que cada um viveu/vive e das simbolizações e subjetivações construídas ao longo da vida." (p. 26)

O presente artigo tem como objetivo apresentar as contribuições de estudos que temos desenvolvido procurando integrar o ensino e a pesquisa junto à formação de professores das séries iniciais do Ensino Fundamental.

\section{0 memorial de leitura e escrita na formação docente}

No âmbito do projeto de pesquisa Memórias e trajetórias de pedagog@s em formação: entre distâncias e abismos reais, virtuais e acadêmico-culturais (CORRÊA, (2011) ${ }^{3}$, analisamos os memoriais de leitura produzidos pelos alunos que apresentaram coeficiente de aprendizagem igual ou superior a nove. Trata-se de um conjunto de 23 memoriais, distribuídos da seguinte forma pelos polos: quatorze de João Monlevade, um de Araguari (num total de quinze alunos em Minas Gerais), dois de Camaçari, dois de Esplanada, dois de Mata de São João, um de São Sebastião do Passé e

3 Projeto PROBIC desenvolvido no âmbito do Centro de Educação Aberta e a Distância CEAD da UFOP; financiado pela FAPEMIG em 2011. 
um de Salvador (num total de oito alunos na Bahia).

$\mathrm{O}$ corpus de nossa pesquisa foi um conjunto de textos do gênero memoriais, construído pelos alunos do curso de Pedagogia - modalidade EaD, da Universidade Federal de Ouro Preto (UFOP). Nosso objeto se pautou nesse gênero pelo fato de que

[...] as memórias se encontrarem num limiar entre a história e a estória, pelo fato de ser o estudante o narrador-observador da história e, finalmente, pelo fato de o cronista se transformar em narrador-protagonista. Por todos esses motivos, pensa-se em trabalhar com o gênero memórias enquanto estratégia de formação [docente e também utilizar esses textos para a produção de conhecimento na área]. (MARTINS, 2005, p. 38)

Os memoriais aqui analisados foram coletados em 14 turmas que os produziram durante a disciplina Ensino e Aprendizagem de Linguagem IV, que se pauta pela discussão das relações entre literatura e escola, ou seja, pela questão da leitura literária na escola.

Esses memoriais apresentam a trajetória de formação de leitores a partir do exemplo de memoriais fornecidos e com o auxílio dos docentes. Os exemplos de memoriais serviram de base para a produção dos graduandos, uma vez que a construção de memorial teria de ser guiada e o texto produzido não poderia se munir simplesmente de lembranças de valor sentimental, ou seja, não se tratava da produção de um diário, mas sim de um texto com um objetivo específico - a trajetória de leitura e escrita do aluno, em que o valor intelectual era indispensável.

\section{Três vidas escritas: das memórias narradas}

Destacamos três memoriais que se sobressaíram entre os demais coletados tendo em vista: i) os coeficientes de aproveitamento dos três narradores; ii) o empenho dos narradores na construção de seus textos, identificado pelo cuidado na edição e editoração do texto e investimento na produção textual; iii) o desempenho dos narradores durante a realização da disciplina em que foi coletado o material; iv) as interações entre narradores e pesquisador antes, durante e depois da coleta dos dados. 
Cada um desses sujeitos é de um polo diferente do curso de Pedagogia do CEAD-UFOP e aqui eles foram identificados por pseudônimos que marcaram suas identidades construídas narrativamente. Valendo-nos da metodologia qualitativa da pesquisa em educação e linguagem, que elege materiais mais ricos em sentidos, optamos pela análise de três memoriais de leitura produzidos.

\section{Lis-Escrevinhadora -}

Nasceu e mora no interior de Minas Gerais, na região do Triângulo Mineiro. É a quinta filha de um casal que teve 14 filhos, com gêmeos e trigêmeos. Tem intenções literárias desde muito jovem (escreve poemas, contos e romances) e já tem três romances publicados com recursos próprios. Trabalha em um cartório e se formou em Pedagogia em 2011. Continua escrevendo e participando de oficinas literárias, incentivada por amigos e ex-professores.

Diferentemente da maioria dos sujeitos da pesquisa, LisEscrevinhadora produziu seu memorial num misto de primeira e terceira pessoas, inclusive rompendo com o tipo de pacto de escrita sugerido pelo gênero discursivo: um memorial pressupõe a escrita em primeira pessoa, singular ou plural, já que se trata da escrita de si, das rememorações individuais e sociais do sujeito que narra sua própria vida.

Caríssimo leitor! Peço licença para abrir-vos um livro íntimo e muito especial para mim. Gostaria de contar algumas passagens do mesmo e confessar que desde meus primeiros contatos com tal livro, nunca mais o deixei. Peço que não se afobe e nem tenha tanta curiosidade, pois que, logo mais lhe será revelado no fim destas notas, mesmo que isso não lhe será necessário, pois conhecereis a partir das cenas que forem se desenrolando ao longo de cada capítulo, de que e de quem se trata tal livro. É um livro de muitas aventuras, de muitas histórias compartilhadas e guardadas.

Começo pelo capítulo do nascimento da personagem principal deste romance, sim, pois o queéa vida senão um romance? Um lindo e mágico romance onde tudo acontece no tempo real. Nove de janeiro de 1960, nasceu nossa personagem “Lis", vindo na sequência de quatro filhas, depois vieram outros irmãos, abaixo nasceram mais dez, sendo sete homens e três mulheres. (grifo nosso)

Os leitores mais versados na norma padrão identificarão problemas 
no uso da segunda pessoa, que varia, no memorial, entre o singular e o plural. Ao mesmo tempo em que a narradora se dirige a um leitor, no singular, também utiliza o pronome oblíquo "vos" de segunda pessoa do plural ou a forma "conhecereis". A narradora utiliza uma estratégia discursiva que tem suas relações com a narrativa do escritor Machado de Assis, o que se explica pelo trecho abaixo:

Alguns anos depois, quando já se via estruturada financeiramente, podendo bancar os prejuízos de suas sandices, escreveu um romance e pediu para sua irmã que era professora e pedagoga para dar uma olhada. F leu os rascunhos e disse: "Lis a história é linda, mas acho que deveria de enriquecê-la com mais detalhes, lembra dos livros de Machado de Assis, como ele detalha um personagem, um lugar? Pois é, são os detalhes que enriquecem um livro".

O trecho acima aponta para a sugestão de influências que a narradora teve daquele que talvez seja o mais canônico dos escritores brasileiros, Machado de Assis, conforme sugerido pela irmã - primeira leitora de sua produção literária.

Vejamos agora alguns excertos em que Lis-Escrevinhadora relata suas experiências escolares mais remotas:

Lis foi para a escola aos sete anos, matriculou-se na Escola Estadual A M. O prédio da escola era uma construção feita de metal, que as crianças da outra escola chamavam de "escola de lata", o prédio da outra escola era construído de alvenaria, por isso havia certa rivalidade entre os alunos de ambas. Não havia pré-escolar, todas as crianças se matriculavam na $1^{\mathrm{a}}$ série. Seu primeiro contato com a escola não poderia ter sido mais marcante. A primeira professora, tinha o nome e sobrenome de Lis, sem contar que, como numa cidade pequena todos se conhecem por apelidos, esta tinha o mesmo apelido que ela. Seu primeiro dia foi triunfal, chegou em casa, sentindo-se a mais feliz de todas as crianças da rua.

Alguns meses de alfabetização no método global, "Dos três porquinhos, Palhaço, Palito e Pedrico" e Lis já soletrava algumas palavras. Adorava as atividades de leitura. Não era a primeira aluna da classe. Não podia contar com muita ajuda da mãe, que a cada ano concebia mais um filho. A casa parecia uma creche. Mas, Lis não podia se queixar da mãe, que mesmo tendo só o curso primário, de escola rural, a incentivava e nunca deixava de olhar seus objetos escolares. Sempre brigando por causa das "orelhas de burro" nos cadernos. Não teve muitas regalias, os cadernos 
eram de brochura, exatamente como aqueles apresentados por Décio Dias nos Slides "Coisas da escola de antigamente." Muitas daquelas coisas, fizeram Lis brilhar os olhos e suspirar de recordação. Lis conta que aprendeu o hino nacional na capa de um deles. Carregava seus objetos na mão, não tinha mochila, aliás, não havia mochila naquele tempo, (não na sua escola) as mães costuravam umas sacolas quadradas feitas de retalhos e colocavam os cadernos, lápis e borracha. Canetinhas eram para as meninas ricas.

Lis se encantava com os cadernos da D, filha da diretora D. T M. Interessante que D um dia lhe ensinou a lavar pratos.

O trecho mostra a relação de Lis com a escrita desde o processo de alfabetização, apontando, inclusive, o método pelo qual fora alfabetizada, o método global de textos, bastante comum em Minas Gerais à época. Também é importante ressaltar a maneira como a narradora descreve a participação tímida de sua mãe nesse processo: com tantos filhos e pouca escolaridade, o auxílio da mãe nas tarefas escolares não podia ser muito grande, mas a mãe zelosa não deixava de avaliar os objetos escolares dos filhos, cuidando para que os cadernos não tivessem as chamadas "orelhas de burro", que demonstravam desmazelo. Vale ressaltar ainda a referência a um material utilizado na disciplina ministrada, em que foram apresentados objetos utilizados nas escolas das décadas de 50, 60 e 70, no Brasil.

Em outro excerto, Lis-Escrevinhadora mostra como se enveredou pelas leituras populares e ao mesmo tempo proibidas - leitura de entretenimento, destinada a público predominantemente feminino durante sua adolescência:

Os anos passados no Ginásio foram marcados com muitas fantasias, e muitas leituras. Lis adorava ler, lia tudo que via. Gostava tanto de ler, que acabou criando problemas em casa. Havia uma amiga, $\mathrm{U}$, mulher já casada que tinha muitas revistas de fotonovelas. Talvez o leitor, não tenha vivido o tempo das fotonovelas, eram revistas em quadrinho, do tipo das revistas da turma da Mônica, porém maiores e as histórias eram romances lindos, apaixonados, melodramáticos. A amiga lhe emprestava as revistas e Lis as devorava. Sua mãe sempre brigava, por que Lis simplesmente sumia e não ajudava com as tarefas de casa. Um dia a mãe levantou o seu colchão e quase morreu de susto (Era expressamente proibido 
mocinhas ler ou ver revistas de romances) e sua mãe, não sabia o que fazer. É verdade que Lis andou recebendo uns castigos, mas ainda assim, escapulia e lá estava ela de volta a trocar as revistas com a amiga $U$. Lis acredita que isso lhe rendeu boas relações com leituras e textos e que de certa forma, a ajudou sair-se bem em redações do colégio. Gostava de participar dos grêmios estudantis e tinha muito jeito para encenações.

A narradora revela, nesse excerto, um hábito bastante comum às moças brasileiras dos anos 60 e 70, o de ler as revistas de fotonovelas: histórias de amor e traição que eram fotografadas e "quadrinizadas". Trata-se de um tipo de leitura que se popularizou bastante entre o público feminino, competindo e por vezes substituindo a leitura dos chamados "romances açucarados", comuns em bancas de revistas e bibliotecas populares.

Lis-Escrevinhadora começou a desenvolver o gosto pela escrita literária na escola, no antigo curso secundário, até conseguir publicar suas próprias obras, como narra detalhada e emocionadamente em seu memorial, devidamente registrado com fotos de sua noite de autógrafos na Bienal do Livro do Rio de Janeiro, em 2009:

Mas teve que retornar à Lagamar por motivos familiares, e aî ingressou-se num outro curso, o magistério da Escola Estadual A A e foi nessa época que Lis descobriu-se uma exímia leitora e a escrever alguns rabiscos, contos compridos, poesias que eram engavetadas, aventurando-se também a intitular-se "escritora". A partir de um trabalho pedido pela professora de português, Dona $\mathrm{M}$, que pediu para os alunos escreverem uma historia, do assunto que desejassem, e deu certo prazo não muito pequeno, para a entrega dos trabalhos. Esse trabalho valeria a nota da prova daquele bimestre $[\ldots]$

Lis relata que esse trabalho a empolgou de tal forma, que a sua história, foi ganhando grandes proporções, cenários, enredos, personagens diferentes, começaram a entrar no seu texto transformando-o num conto que tinha como título: "A garota repórter". [...]

Ao devolver os textos dos alunos, a professora elogiou o texto de Lis, incentivando-lhe e valorizando a escrita dela:

"Agora quero dar meus parabéns a aluna Maria e falar para vocês sobre o texto dela". Dona M, comentou com os alunos a história de Lis, depois disse: "Lis, onde você tirou tudo isso"? Já sabendo 
que os trabalhos de Lis sempre foram muito bem elaborados e que jamais seria capaz fazer plágio. (Plágio?), Lis só viria a saber disso muito anos mais tarde. Dona $\mathrm{M}$ disse que mesmo sem ter concluído o final da história, Lis merecia nota dez e que continuasse a escrever, que escrevesse muito mesmo, pois ela possuía muito dom literário e todas as características de uma escritora.

Continuando o seu memorial, Lis revela que a possibilidade de publicação de seus textos surgiu anos mais tarde, tornando seu sonho um projeto realizado:

Publicar era um sonho muito distante.

$[\ldots]$

Peguei novamente os rascunhos e fiz o que a F me disse. Depois resolvi pedir à professora de Literatura $\mathrm{R} F$, para dar uma lida. Disse à professora: São apenas rabiscos, mas tenho muita vontade de que alguém da área de letras os leia. $\mathrm{R}$ leu os rascunhos e retornou entusiasmadíssima: “Que linda história! Você vai publicar sim!".

Lis se elevou, não pensou que fosse ser tão elogiada. E a professora, deu ainda muitos empurrões, como revisar o texto, por uma, duas vezes e orientou Lis para procurar um revisor de textos profissional.

Foram sete meses de espera desde o primeiro dia que Lis entregou o texto do livro na CBJE, Câmara Brasileira de Jovens Escritores, do Rio de Janeiro. Enfim a tão esperada encomenda chegou pelo correio. Lis nunca havia recebido via correio um volume daqueles. São meus livros pensou. A surpresa foi tamanha que Lis rasgou rapidamente os papeis que envolviam a caixa e ao ver a capa não se conteve, as lágrimas rolaram pela sua face, enquanto chorava Lis dizia abraçada ao livro: "Eu consegui, eu consegui! Meu livro, eu publiquei meu livro!"

O relato de Lis culmina com a publicação de sua primeira obra, quando a "escrevinhadora" vê, pela primeira vez, seu nome impresso na capa de um livro, estava realizando um grande sonho. O leitor deste artigo pode perceber que, a despeito dos desvios da norma linguística, existiu um grande empenho na produção textual, imprimindo ao texto, inclusive, características da linguagem literária, ao mesmo tempo em 
que a narradora vai revelando seus sonhos e desejos.

Payayá-Índio-do-Brasil - Nasceu no interior da Bahia, na região da Chapada Diamantina, considera-se sertanejo e indígena, caçula de uma família de oito filhos. Tem intensa militância pela causa indígena no Brasil.

A descrição do sujeito Payayá-Índio-do-Brasil feita acima é muito breve e não é suficiente para dar ao leitor a dimensão de sua autodescrição no memorial produzido por ele. Por esse motivo, transcrevemos abaixo os seus primeiros parágrafos:

Sou o caçula dos oito filhos de $\mathrm{P}$, que faleceu quando eu tinha quatro anos e meio, e de M. Ambos lavradores. Neste ofício, minha mãe, munida da obstinação, síntese da sertaneja que empunhada de coragem, machado, enxada e facão, cumpriu as duras penas na missão de arrancar o pão diário para sua penca de filhos, lá no pé de serra da Chapada Diamantina, que preferem chamá-lo de Piemonte, no município de Miguel Calmon, ex-Canabrava, terras imemoriais dos índios Payayá, da grande nação Kariri, falantes de língua do tronco macro-jê. Foi nesse chão com tudo o que nele se transformou - nasceu toda a rama ancestral da minha mãe para depois - desses fios, sermos também gerados.

Embora o destino mais procurado para a debandada dos conterrâneos que fugiam da seca e de outras situações fosse São Paulo ou Rio de Janeiro, meus irmãos mais velhos: A, A, Á, A (in memoriam), A (caçula das mulheres), rumaram para Salvador em busca da sobrevivência. A, meu irmão excepcional, minha mãe e eu, ficamos por lá e continuamos a tocar as roças no trabalho de meia. Saímos bem mais tarde, nas imediações do pouso do Apolo 11 na Lua (20 de julho de 1969). Eu tinha 10 anos de idade quando chegamos como retirantes na capital da "Bahia"!

Entre diáspora e saga, queria entender esses lampejos que às vezes se emendam com finas divisórias entre realidade e memória lacunada ou algo assim: essa compreensão é só minha ou alguém mais viveu isso? Entretanto, no passado não havia "cultura" familiar para ler essas transformações e muito menos ressignificálas: falecimento do nosso pai, perda da terrinha, dos animais, sobrevivência de meia, de adjutório, mãe analfabeta, situações adversas, falta de recursos materiais, baixa escolaridade, parentes e amigos deixados para trás, enfim, trouxemos no jirau da memória os referenciais identitários da cultura sertaneja - hibridismo das matrizes que formaram o povo brasileiro. 
Essa hibridez (aridez também) vem das veredas que fazem do sertão sertões. Há vários sertões no sertão de Canudos visto por Euclides da Cunha. Se o sertão que é em todo lugar - como dizia Guimarães Rosa - então ele é pau imenso para além da terceira margem, sem eira nem beira - pois coexiste em qualquer lugar. Os sertões percorridos por Lampião e Maria Bonita, por Corisco e Dadá e os cabras deles. Os sertões das rezadeiras, carpideiras e curadores. Os sertões dos vaqueiros encourados e rencas de ciganos.

Sertões dos povos indígenas que foram expulsos da costa brasileira. Os sertões dos africanos, numerosamente das culturas banto que umbundou o português arcaico babatando vaçuncê, vosmicê nas incelenças e inclemenças nos sertões dos europeus abrasileirados. Sertão das emboladas e dos cordéis. Sertões dos coronéis, dos párias da pátria ou de tabaréus (aquele que deixou a taba). Sertõeszinhos para rocinhas pequenininhas de uma gente que foi sendo amiudada com dias contadinhos de vidinha ou fugindo pras cidades tais Severinos de pia - enquanto os sertões dos latifúndios de terras sem fim que se iam abrindo mais e mais os limites de suas cercas com as patas do gado que expulsaram os nativos para o deserto das cidades ou os escravizaram ali mesmo.

Sertões das vivências culturais que permitem ver/ouvir/sondar a anunciação das chuvas nos pios da araponga ou nos céus "ramiados" na convivência com a seca, brejos poucos e muitas caatingas que tem por espantalhos os mandacarus, xiquexiques, macambiras, barrigudas, cascalhos, cascavéis, léguas tiranas e o encalço quase sempre fatigado por sua geografia da resistência, pouca ou nenhuma escola, minguada saúde e o desmantelo da fome que o obstinado Josué de Castro perseguiu essa clássica esfinge e estivera também no percalço de Paulo Freire que a viu revirar suas tripas em Jaboatão como ele mesmo disse após a perca do pai: “[...] experimentei o que é a fome e compreendi a fome dos demais".

Sobrevivemos, contudo. Cada um do seu jeito e na ausência desse deixamos nosso lugar, nossa gente e arribamos dali. Mais alguns que fizeram do êxodo rural o caminho da cidade com suas arapucas, tocaias, às vezes cheia, outras tantas, deserta daquilo que lá fomos buscar. Mas como a vida é uma caminhada - borandar qui a chuva inda nun chegô.

Escrito com a destreza de quem domina as variedades mais próximas do padrão da língua e, ao mesmo tempo, a fala coloquial do brasileiro, no excerto acima, ficam evidenciados, entre tantos outros, três pontos 
muito importantes e que merecem destaque: i) o grande orgulho pela identidade sertaneja e indígena por parte do narrador, orgulho este também marcado pela consciência do massacre que teve o seu povo e a ocupação da sua terra de origem; ii) a referência explícita ao educador brasileiro Paulo Freire, conhecido pelo seu trabalho de alfabetização combinado com a conscientização e emancipação da classe trabalhadora; e iii) o conhecimento e a apropriação da cultura letrada escrita de escritores brasileiros legitimados pela crítica literária como Euclides da Cunha, Guimarães Rosa, diretamente citados, além de escritores como João Cabral de Mello Neto ou Graciliano Ramos, pelas referências mais ou menos implícitas pelo domínio do recurso discursivo da intertextualidade; além de outros elementos da cultura brasileira como as personagens Lampião, Maria Bonita, Corisco e Dadá e anônimos curadores, rezadeiras e carpideiras.

Muitos pontos podem ser destacados ainda no excerto acima, proporcionando, apenas ele, material para a produção de um artigo de cunho interpretativo, mas avancemos na reconstrução das reminiscências do nosso sujeito.

De mudança com o restante da família para a capital da Bahia, Payayá-Índio-do-Brasil vendeu pipoca e picolé, trabalhou no comércio local e foi empacotador de uma grande rede de supermercados, o que lhe permitiu, ao ter sua carteira assinada, inserir-se no teatro e, ao mesmo tempo, contribuir com o sustento da família:

Essa condição me permitiu fazer teatro, atividade ainda elitizada nos anos 70. Do teatro desejava estabelecer uma ponte que me levasse para as novelas da televisão, a fim de trazer à tona as histórias que estavam fervilhando na minha memória ou nas vozes amiudadas, silentes, cercadas por medo e baixa estima ou condenadas ao subterrâneo.

Mostrando que artista não é malandro, com meu salário já podia ajudar em casa.

$[\ldots]$

Perdido e aculturado sem deixar minhas origens, na cidade grande, o teatro foi porto e catarse para mim. Comecei a entender 
minhas perdas e aos poucos elas passaram a migrar para a teatrologia, para a poesia, para as lutas e para os projetos sociais. A partir dos meados dos anos 70, e, por que não afirmar, com maior ênfase agora, com a formação em Pedagogia, podia sistematizar ideias, conceitos, produzir conhecimentos e saberes e ora, através do arco acadêmico, arremessá-los?!

Do teatro, Payayá chegou aos movimentos sociais e, algum tempo depois, à Universidade. Mas, para chegar ao curso de Pedagogia, foi uma longa trajetória. A primeira experiência com a escola não foi das melhores. Acostumado que estava às brincadeiras no campo, ao ar livre, mesmo com todas as adversidades e com o trabalho a ser realizado desde muito cedo, Payayá assim narra mais um pouco da sua trajetória e suas escolhas de leitura:

Nunca tive tempo, nem tampouco fui seduzido por best-sellers ou receitas. Não que busque "o mais difícil", porém me aproximo mais de certos personagens, como Ahasverus, Fernão Capelo Gaivota, Uirás. Embora encontre auxílio e elucidação nos referenciais, meu desejo era buscar o "caminho de volta. Por isso eu via matutando sobre o curupira". Faço isso ao caminhar caminhos $e$ (des)caminhos, conquanto esteja inteiro no que estiver fazendo. Minha autoralidade é antropofágica. Embora se alimente de tudo o que vê, come, bebe, lê, não se satisfaz se não se autoidentificar. Tem de ser cúmplice e encontrar reciprocidades. Sou assim, incorporar e ser coletivo, entretanto, mesmo tendo tanto a aprender, tenho cá comigo meus pontos de amarração.

Aquelas "marcas", só agora mais diluídas, posso convertê-las em algo suportável, na medida em que mergulhei em constantes ações-reflexões sobre esses fenômenos. Enfim, consolido tudo isso na escolha pelos projetos socioambientais, com índios, quilombolas, e enfaticamente, agora, pela educação. Felizmente ela sempre esteve amalgamada em toda ação desenvolvida e afirmo que era por uma educação da libertação, embora não conhecesse a teoria do educador Paulo Freire, mas que trazia essa utopia por causa da minha inserção nos movimentos citados. (grifo nosso)

O último parágrafo mostra como Payayá se apropriou do conhecimento acadêmico e como este trouxe a ele a conscientização de que, mesmo sem conhecer os trabalhos do educador Paulo Freire, Payayá tinha a mesma utopia teorizada pelo mestre. 
A trajetória de Payayá pela escola é, como ele mesmo afirma, entre idas e vindas, constituída mais de vindas. Excluído da escola e da sociedade, como se depreende de sua poética e consistente narrativa, Payayá, a partir do contato com o universo teatral, vai se constituindo como sujeito atuante e militante em seu meio e consegue se formar na Educação Básica por meio dos programas de suplência. Submetese, então, a dois processos seletivos para universidades públicas e é aprovado em ambos. Leiamos a própria narrativa de Payayá:

Fases e ciclos marcaram minhas poucas idas - das muitas vindas das escolas. Da infância ao Ensino Médio, poucas vezes estive entre quatro paredes assistindo às aulas, motivo pelo qual tive que fazer as atividades da Educação Integrada, correspondentes às séries iniciais do $1 .{ }^{\circ}$ Grau, depois os Exames de Suplência de Educação Geral, como também o Exame Supletivo do $2{ }^{\circ} \mathrm{Grau}$, sem nunca cursar uma disciplina. Passei em todas e fiquei devendo apenas Matemática. Só voltei a prestar Exame em 2006, quando, enfim, fui aprovado na referida disciplina e conquistei o canudo, após uma espera de 29 anos para concluir o Ensino Médio.

Claro que a situação de fracasso escolar me deixava travado. Contudo haveria de romper com as tranqueiras de pau pela frente. Mas, como? Sozinho? O super-homem não virá, nem Corisco ou Lampião, tampouco meu saudoso pai - meu grande herói. Minha mãe, estupenda heroína, sua habilidade era outra: sobreviver da roça, da roça, da roça!

Muito por causa das minhas interações, particularmente, com o povo do teatro, passei a fazer outras leituras e entender por que estranhava a cidade grande e as regras do capitalismo e, por fim, o que estava por trás das palavras-chave: exclusão social, aculturação, autoestima, marginalização, identidade, subalternidade, trânsito. Saquei drummondiando "a pedra no caminho" [...] "o vasto mundo" [...] para sobreviver sem minhas raízes, decifrando coisas e entes, quando, sem saber, empiricamente interagia com Freire nas minhas primeiras leituras de mundo.

Quando recebi o canudo do $2 .^{\circ} \mathrm{Grau}$, eu me prometi que iria fazer o que tantos me recomendavam: ingressar no ensino superior. $\mathrm{Na}$ primeira oportunidade que surgiu, fiz o vestibular de Ciências Sociais para o ensino presencial na Universidade Federal da Bahia (UFBA) e, concomitantemente, participei do processo seletivo de Licenciatura em Pedagogia da Universidade Federal de Ouro Preto 
(UFOP). Resultados: fui aprovado nos dois e, sem relutar, optei pelo curso de Pedagogia - essa opção reflete as pessoas com as quais interagi, ao longo das minhas caminhadas.

Payayá faz também, em seu memorial, considerações sobre as condições da Educação a Distância, ainda cercada de preconceitos e falsas percepções:

Embora não seja nova esta modalidade de ensino [EaD], há aqueles que têm dificuldade de se adequar e precisam de um tempo maior para lidar e interagir com o modelo. Talvez ainda prefiram ou precisem da presença de professores e de colegas, como no ensino tradicional. Alguns dizem que sentem dificuldade de diálogo e de resolução de dúvidas e que há um descompasso com referência à apropriação do conhecimento. Ao contrário desses raciocínios, acho que, por meu perfil de autodidatismo e de autoformação, sou um dos mais felizes aprendentes da EaD no Brasil. Ao contrário do passado, já ampliei minha percepção e não tenho indisposição quanto ao ensino presencial, o que me faz lembrar o professor Paulo Freire: "A alegria não chega apenas no encontro do achado, mas faz parte do processo da busca".

Muitas críticas foram feitas ao modelo de EaD proposto pela universidade, tais como: a pouca interação entre professores e alunos, as dificuldades de transporte e acesso aos Polos de Apoio Presencial, a precariedade da tecnologia, o feedback tantas vezes esperado e poucas vezes recebido, o desânimo e desapontamento de colegas de turma, entre outras. Não sem também tecer considerações sobre o empenho de muitos dos sujeitos envolvidos no processo, como professores, tutores presenciais e a distância, Payayá é o exemplo de que, conquistada a tão esperada autonomia, é possível que o aluno da EaD se desenvolva tanto quanto um aluno da modalidade presencial.

Ao continuar a sua narrativa memorialística Payayá-Índio-do-Brasil ainda evoca o pensamento de estudiosos como Jean-Paul Sartre, Gaston Pineau e Humberto Maturana, num texto que demonstra maturidade acadêmica, na reflexão e na concretização dessa reflexão na forma da produção textual.

Violeta-Prô-da-Bahia - Nasceu no interior da Bahia, filha de mãe solteira, teve uma vida difícil, conforme relata. Tornou-se professora, apesar de todas as dificuldades. Assim Violeta começa a sua narrativa: 
Nasci em 21 de julho de 1950, em Cravolândia, interior da Bahia. Filha de M E B dos S, meu pai biológico eu não conheci nem tive seu nome em meus registros de nascimento. Nenhuma foto, nenhum dado que fortalecesse o vínculo paterno. Soube por minha mãe, quando tive um problema cardíaco, que ele havia falecido de enfarto. Por alguns anos sofri com esta negação, mas também minha genitora nunca me falou e eu também nunca procurei saber. Esta situação vim absorver e aceitar com a maturidade, não sei se por causa disso sempre fui muito tímida, retraída e não me sentia à vontade de fazer muitas amizades, tinha receio e medo de me magoar. (grifos nossos)

Violeta produz um memorial emocionado e emocionante, em que se apresenta por inteiro, desvelando, inclusive, suas questões mais íntimas e seus sentimentos mais profundos, salientados nos grifos acima e retomados nos grifos do próximo excerto.

As dificuldades com a escrita são muitas e Violeta tem bastante consciência delas, como observa:

A atividade de escrever para mim ainda é um ato difícil, por no papel o que vem a minha mente, procurando expressar o que é necessário pelo medo de tropeçar nas palavras, de errar, de não evidenciar os meus anseios, vontades e desejos através da escrita. Reencontrar com minha memória, adentrar o meu interior sem que tenha que pedir autorização a mim mesma, tentando ultrapassar os meus limites como pessoa, falar do meu eu, e de todo o meu caminhar até o presente momento, sem medo de exercer a felicidade, praticar a liberdade, exercer a comunicação, sentir-me aberta para uma realização que chegou nesta etapa de minha existência que é concluir a minha graduação.

Envolver-me num trabalho biográfico de minha vida, relatar fatos que para mim foram demais significativos com fidelidade e tranquilidade, retomar a evolução da minha história particular que é minha referência como indivíduo e pessoa que procura apesar da idade estar em sintonia com o mundo, com o outro de forma harmônica e feliz. (grifo nosso)

Violeta deixa entrever, em sua narrativa, a força de ultrapassar as barreiras colocadas pela vida e o desejo de vencer a timidez e se abrir consigo mesma e com o outro. Concluir um curso de graduação foi um sonho que se realizou.

Assim, Violeta narra sua relação com os professores dos primeiros anos escolares: 
Tive um bom relacionamento com todos os professores da escola primária, a diretora me adorava e aceitou que fizesse o curso de admissão para o ginásio em turno oposto no ano de 1963, já com treze anos. Tínhamos respeito a todos da escola independente da hierarquia, tratávamos com educação e carinho. Existia um clima de tranquilidade e harmonia, imperava a paz, a ordem e o amor. Sempre fui ordeira, educada, obstinada em colocar os meus estudos em primeiro plano. Nunca fui inteligente, mas esforçada e caprichosa. Andava impecável nas minhas obrigações como aluna e a tudo era convocada para representar a escola, onde quer que fosse. Sempre tive uma boa comunicação com toda a comunidade escolar. (grifo nosso)

Nesse excerto, é interessante observar como Violeta se percebe: obstinada, esforçada e caprichosa. Mas nega a si mesma o adjetivo inteligente. É como se a inteligência fosse algo natural e fluido, que não dependesse de um esforço. Embora fuja aos objetivos deste artigo, vale uma pequena reflexão sobre essas representações que a escola carrega de seus alunos: adiantados, esforçados e/ou inteligentes.

Abaixo, Violeta narra sua inserção no mercado profissional, ao retomar os estudos 12 anos depois de formada e com os filhos já crescidos:

A minha experiência profissional teve início em 1982, doze anos depois de formada, quando também ousei fazer o curso de Adicionais em Língua Portuguesa no turno da noite e a oportunidade de trabalhar um turno como Auxiliar Administrativo, na parte da secretaria de uma escola, os meninos já estavam crescidos e me senti com coragem para enfrentar esta nova proposta de vida. Nesta época eles já estudavam e neste mesmo período eu trabalhava. Saíamos juntos! Concluíaos troncose barrancos o curso, pois tive vários obstáculos. Fui determinada e terminei.

Até aí nada de pensar em fazer faculdade! Neste ponto não fui corajosa o suficiente para encarar uma vida acadêmica. Sempre tive o incentivo de amigos e dos familiares e no ano de 1985 entrei para trabalhar na prefeitura da cidade de Salvador como professora. (grifo nosso)

A entrada na universidade e o trabalho realizado no âmbito acadêmico promoveram a autoestima de Violeta, conforme se pode depreender pelo excerto abaixo:

Este curso mudou minha trajetória de vida. Me fez acreditar em 
mim, me fez uma pessoa confiante, me proporcionou um percurso além do que poderia imaginar que fosse capaz, me tornou possível olhar o quanto sou capaz de realizar e chegar a um determinado lugar, alcançar e alçar voos distantes, olhar para dentro de mim mesma e ver que não sou nada daquilo que eu achava que era: incapaz, ineficiente... me tornou uma pessoa madura, que hoje se enxerga com outro olhar!

Hoje me tornei uma profissional e aluna aprendiz realizada, não como gostaria que fosse, porque o tempo não me permite chegar mais longe, mas como disse anteriormente, temos que nos adaptar ao mundo. Me relaciono muitíssimo bem à distância com colegas, tutores presencias e à distância, coordenação, Professores Doutores e Mestres, tudo de maneira autônoma, sem medo de ser feliz! Orgulhome de estar estudando numa faculdade com Professores Doutores e Mestres, pesquisadores em excelência, o que para mim tomo como modelo. (grifos nossos)

O excerto acima aponta para a importância da formação superior na vida da narradora: não foi apenas a conquista de um título, mas a construção de uma identidade mais confiante, a recuperação de uma autoestima perdida.

Violeta estabeleceu, durante o curso, intensa interação com os envolvidos no processo da EaD: colegas, tutores e professores, conseguindo se letrar digitalmente. Continua suas narrativas, refletindo sobre sua vida:

É bastante cansativa e árdua a rotina que desenvolvo, mas que exerço com vontade, carinho e muita força de querer chegar lá! Às vezes sinto-me uma jovem estudante, no início de seus estudos, ansiosa por fazer o melhor do que posso em relação as minhas atividades acadêmicas. Sempre direciono aos meus três netos como forma de exemplificar, que quando era criança sempre tive essa percepção de fazer a mais do que era solicitado. Nunca me satisfazia com pouco.

Elaborar este documento, ter a oportunidade de colocar no papel minhas impressões, relatar os acertos, as vitórias, os avanços, mas também as falhas, os momentos difíceis, as paradas, as dúvidas - que não foram poucas, as incertezas, as emoções, descobertas, os sucessos e insucessos. Perceber o quanto este curso à distância me fez reavaliar minha prática pedagógica, promover e praticar a auto-avaliação, como as atividades puderam interagir com as 
mudanças e transformações comigo e com o meu aluno. Superar minhas limitações enquanto pessoa, melhorar a minha leitura, escrita, também a pesquisa, tudo tem sido muito intenso.

Violeta produziu um memorial reflexivo, crítico e muito emocionante e emocionado, como já relatamos. Se, diferentemente de Payayá, não cita vários escritores e teóricos que marcaram sua vida, vê na produção do memorial a oportunidade para falar dos seus medos, dos seus anseios e também da superação de cada uma das etapas vivenciadas.

\section{Alguns comentários finais}

Como se pôde observar, dos três memoriais aqui analisados mais detidamente, apenas um deles é de uma professora regente de turmas: Violeta-Prô-da-Bahia. Payayá-Índio-do-Brasil, embora trabalhe com educação, ministrando oficinas e palestras, não se intitula professor em momento algum. Estranhamente, em seu currículo Lattes, também não apresenta sua formação de graduação, mencionando apenas seus cursos de aperfeiçoamento. Lis-Escrevinhadora parece ter seguido o caminho do pai, herdeira de cartório, tornou-se escrivã. Embora bem diferente das aspirações de um escritor de literatura, o escrivão é, também, um profissional da escrita, como o próprio nome da profissão já diz. LisEscrevinhadora optou pelo curso de Pedagogia por ser aquele oferecido pela UFOP no polo de sua cidade. Payayá-Índio-do-Brasil optou pelo curso de Pedagogia, mesmo tendo sido aprovado no vestibular para o curso de Ciências Sociais, presencial, em uma universidade pública federal. Talvez a distância de sua casa, já que essa instituição pública fica na capital da Bahia, Salvador, e o fato de o curso demandar a presença diária em pelo menos um turno, tenha sido mesmo o fator que levou Payayá a optar pela Pedagogia, uma vez que os dois cursos têm a ver com os trabalhos que ele já vinha desenvolvendo desde sua adolescência e juventude. Dos três, Violeta é a que apresenta maior dificuldade com a escrita e com a norma culta da língua portuguesa, como se pode depreender pelos excertos aqui transcritos. Mas os três sujeitos produtores dos memoriais aqui analisados fizeram a diferença no curso de Pedagogia EaD da UFOP enquanto foram seus alunos e mesmo depois disso, por meio de suas interações constantes 
com professores, tutores presenciais e a distância. São três sujeitos cujas trajetórias, marcadas por desejos e sonhos, dificuldades, força de vontade e esperança, devem ser conhecidas por um número maior de pessoas da comunidade acadêmica e demais interessados.

Fizemos aqui apenas um exercício de recorte e comentários interpretativos dos três memoriais, para que seja dada uma certa visibilidade a esses pedagogos formados por nossa instituição. Temos a certeza de que o material por nós coletado renderá ainda muitos outros trabalhos e, apenas esses três textos também renderiam, se analisados sob diferentes perspectivas teóricas, belos trabalhos de natureza acadêmica: sociológicos, antropológicos, pedagógicos, linguísticos e até mesmo de análise literária.

A produção de memoriais de leitura e escrita tem sido, dessa forma, uma prática constante do nosso fazer docente, do ensino da graduação, que possibilita ao pedagogo em formação refletir sobre sua trajetória, ler outros memoriais produzidos por outros graduandos e por professores, e também têm sido utilizados na produção da pesquisa acadêmica, por meio da orientação de trabalhos de iniciação científica e de mestrado. Dessa forma, temos tido a intenção de que ensino e pesquisa sobre formação docente andem de mãos dadas na instituição em que atuamos como professores e pesquisadores. 


\section{Referências}

BRASIL. Lei n. 9.394, de 20 de dezembro de 1996. Estabelece as diretrizes e bases da educação nacional. Brasília, DF: Diário Oficial da União, 23 dez. 1996. Disponível em: <http:/ / www.planalto.gov.br/ ccivil_03/leis/19394.htm>. Acesso em: 25 nov. 2013.

BRASIL. Conselho Nacional de Educação. Diretrizes Curriculares Nacionais para a Formação de Professores da Educação Básica. Parecer CNE/CP n. 01/2002. Brasília, DF: Diário Oficial da União, 9 abr. 2002. Disponível em: <http://portal.mec.gov.br/cne/arquivos/ pdf/rcp01_02.pdf>. Acesso em: 25 nov. 2013.

CORRÊA, Hércules Tolêdo. Memórias e trajetórias de pedagog@s em formação: entre distâncias e abismos reais, virtuais e acadêmicoculturais, 2011. (Reprodução).

MARTINS, Aracy Alves. Memórias de professores: eventos e práticas de literacia/letramento. Revista Portuguesa de Educação, Braga-PT: Universidade do Minho, v. 18, n. 2, 2005.

NÓVOA, Antônio (Coord.). Os professores e a sua formação. 2. ed. Lisboa: Dom Quixote,1995.

SOUZA, Elizeu Clementino de. A arte de contar e trocar experiências: reflexões teórico-metodológicas sobre história de vida em formação. Revista Educação em Questão, Natal, v. 25, n. 11, p. 22-39 jan./abr. 2006. 